\author{
Romuald GÓRSKI ${ }^{1}$, Hanna DORNA ${ }^{2 *}$, Agnieszka ROSIŃSKA ${ }^{2}$, Dorota SZOPIŃSKA ${ }^{2}$ \\ and Stanisław WOSIŃSKI ${ }^{3}$
}

\title{
EFFECTS OF ELECTROMAGNETIC FIELDS AND THEIR SHIELDING ON THE GROWTH OF DWARF RUNNER BEANS
}

\begin{abstract}
The aim of the study was to determine the effect of electromagnetic fields and their shielding on the growth of dwarf runner bean Phaseolus coccineus $\mathrm{L}$. Three sectors were separated on the device emitting electromagnetic fields: "E" - sector emitting electromagnetic radiation with the predominance of the electrical component, "EM" - sector emitting electromagnetic radiation without domination of its components and "M" - sector with a predominance of magnetic component. Fields generated by the device were also shielded with ADR TEX, a screen based on a nanocomposite in which the electric component of the electromagnetic radiation is absorbed by water dispersed within a dielectric matrix in various ways. The composites exhibit high dielectric absorption and shield electric fields within the frequency range from $\sim 100 \mathrm{mHz}$ to $\sim 100 \mathrm{kHz}$. Electromagnetic fields with the predominance of the electrical component and without domination of its components delayed the initial emergence of runner bean seedlings. Shielding of electromagnetic field without domination of its components with ADR TEX screen protected against this negative impact on the emergence rate of young runner bean seedlings. Exposure of plants to differentiated electromagnetic fields adversely affected their growth. Plants exposed to electromagnetic radiation without domination of its components had the lowest height and the shortest internodes. Shielding of electromagnetic fields with ADR TEX screen efficiently protected against their negative impact on the plant growth. Electromagnetic fields and their shielding did not influence the size of leaves and the index leaf greenness (SPAD).
\end{abstract}

Keywords: electromagnetic fields, ADR TEX shielding, growth, runner bean, SPAD Index

\section{Introduction}

All living organisms, including humans, animals and plants are exposed to electromagnetic fields. The sources of electromagnetic fields are permanent magnets, electrical appliances, power lines, electric wiring and also natural sources such as the Sun. The intensity of the constant electric field near the earth's surface varies and amounts to $100-150 \mathrm{~V} \mathrm{~m}{ }^{-1}$, while the induction of the Earth's magnetic field is in the range of 30-60 $\mu \mathrm{T}[1]$.

Studies carried out so far have shown differentiated effects of electromagnetic fields on the plant growth, development and physiology. Gemici et al. [2] reported an increase in abscisic acid (ABA) content and a decrease in gibberelic acid $\left(\mathrm{GA}_{3}\right)$, chlorophyll $\mathrm{a}$ and $\mathrm{b}$

\footnotetext{
${ }^{1}$ Department of Entomology and Environmental Protection, Poznań University of Life Sciences, ul. J.H. Dąbrowskiego 159, 60-594 Poznań, Poland, phone +48 618466 336, email: romuald.gorski@ up.poznan.pl ${ }^{2}$ Department of Phytopathology, Seed Science and Technology, Poznań University of Life Sciences, ul. J.H. Dąbrowskiego 159, 60-594 Poznań, Poland, phone +48 618466 384, email: hanna.dorna@up.poznan.pl

${ }^{3}$ ADR Technology, ul. W. Żeleńskiego 18, 80-285 Gdańsk, Poland, email: s.wosinski@adrtechnology.eu

*Corresponding author: hanna.dorna@up.poznan.pl
} 
contents in walnut and cherry leaves exposed to electromagnetic fields of high voltage transmission lines (0.1-10 mG and 50-60 Hz) compared to control trees. High voltage lines had negative effects on the growth and development of the plants. Leaves were thinner and leaf mesophyll was more densely packed than in the case of the control trees. Biketi et al. [3] found that the level of chlorophyll a was lower in plants, which were exposed to $50 \mathrm{~Hz}$ magnetic field with the induction of 0.5-3 mT. On the other hand, Racuciu et al. [4] observed a biostimulatory influence of low frequency electromagnetic field $(50 \mathrm{~Hz}, 10 \mathrm{mT})$ on the biosynthesis of chlorophyll a in pumpkin seedlings after daily 1 hour exposure. The positive linear correlation between contents of chlorophyll a and carotenoids, the acceleration of the plant growth and root development and stimulation of protein synthesis were noticed. Exposure of soybean seeds to $50 \mathrm{~Hz}$ magnetic field with the induction of $30 \mathrm{mT}$ for 1, 2.5 and $5 \mathrm{~min}$ did not affect seed germination, but increased chlorophyll content in seedling cotyledons [5]. Results obtained by Nurbaity et al. [6] reviled that magnetically treated sorghum seeds were characterized by higher percentage seed germination, vigour index, seedling growth, number of leaves, shoot diameter and chlorophyll content than untreated seeds. The best results were observed for seeds treated for $15 \mathrm{~min}$ with 1 and $6 \mathrm{mT}$ magnetic fields. Significant acceleration of seed germination as an effect of electromagnetic field treatment was also observed by Sudsiri et al. [7], who found that oil palm kernels soaked in water and treated with electromagnetic field of $9.0 \mathrm{mT}$ for $4 \mathrm{~h}$ germinated significantly faster than untreated watered seeds.

Rape, grown from seeds exposed to electromagnetic field of $10 \mathrm{mT}$ for $4 \mathrm{~h}$, produced a lower seed yield. However, 1000 seed weight was higher and seed size was bigger than in the case of untreated seeds [8].

Magnetic fields, strong and weak electric fields and electric currents can be classified as abiotic stress elicitors to affect a plant growth and development [9]. Moon and Chung [10] observed that alternating current (AC) electric field with intensity higher than $12 \mathrm{kV} \cdot \mathrm{cm}^{-1}$ and exposure time more than $60 \mathrm{~s}$ inhibited the tomato seed germination. But exposure to electric fields ranging from 4 to $12 \mathrm{kV} \cdot \mathrm{cm}^{-1}$ for shorter time had a positive effect and accelerated seed germination. Molamofrad et al. [11] examined effects of AC high-voltage electric fields $\left(2-4 \mathrm{kV} \cdot \mathrm{cm}^{-1}\right.$, exposure time $\left.15-150 \mathrm{~s}\right)$ on onion seed germination percentage and dry weight of seedlings. The maximum increase in seed germination was found after exposure to electric field of $9 \mathrm{kV} \cdot \mathrm{cm}^{-1}$ for $45 \mathrm{~s}$, whereas the highest dry weight of seedlings was noticed at field intensity of $2 \mathrm{kV} \cdot \mathrm{cm}^{-1}$ and exposure time $45 \mathrm{~s}$. Janositz and Knorr [12] reported that the exposure of tobacco protoplasts and cells with cell wall to pulse electric fields with strength of $0.25-7.5 \mathrm{kV} \cdot \mathrm{cm}^{-1}$ and frequency $2 \mathrm{~Hz}$ resulted in a disruption of cell membranes. Both cell types showed higher degree of cell disintegration with application of higher field intensities. The extent of protoplast cell rupture was nearly twice as high compared to the cells with cell wall, demonstrating the protective effect of plant cell walls.

In previous studies conducted by two co-authors of this study, the harmful effects of the electromagnetic field of low frequency $50 \mathrm{~Hz}$ on humans was found. A significant effect of radiation on male fertility has been demonstrated by the deterioration of the studied sperm parameters [13] and accelerating the growth of neoplastic cells of prostate cancer [14]. Despite the fact that in the case discussed we deal with an electromagnetic field of low frequency $(50 \mathrm{~Hz})$, it turns out that this radiation is not indifferent to humans. The influence of the external electromagnetic field on humans depends mainly on the field frequency and its intensity. The values of EMF to which people are exposed in their 
everyday environment require the body to activate appropriate compensation mechanisms in order to minimize such environmental stress. However, long-term exposure to even minimal EMF has negative health consequences, resulting from biological reactions that cause a noticeable weakening of the body over time [15].

In 2002, the International Agency for Research on Cancer (IARC) published a monograph on the evaluation of carcinogenic risks of static and extremely low-frequency (ELF) electric and magnetic fields to humans [16]. In many countries, the standards regarding permissible electromagnetic field are being radically tightened, especially for devices operating in the vicinity of places where people may live or work. According to the IEEE C95.1-2019 standard, at $50 \mathrm{~Hz}$ whole-body exposure, in an "uncontrolled" environment (low level), the ERL (Exposure Reference Limits) for electric field strength is $5000 \mathrm{~V} \cdot \mathrm{m}^{-1}$, while the maximum value is the ERL of the magnetic induction is $0.904 \mathrm{mT}$ [17].

The above results, indicating the negative impact of low-frequency electromagnetic field on the human body, prompted the authors to undertake similar studies on plants. Dwarf beans, which grow relatively fast, were selected as the model plant. The experiment used the frequency of $50 \mathrm{~Hz}$ to simulate the conditions that occur in the environment of humans and growing plants. An electromagnetic field of this frequency is emitted by electrical installations in our homes and power transmission lines.

The aim of the study was to determine the effect of electromagnetic fields and their shielding on the growth of Phaseolus coccineus $\mathrm{L}$.

\section{Material and methods}

Seeds of dwarf runner beans Phaseolus coccineus L. were sown in plastic pots of $10 \mathrm{~cm}$ diameter and $0.5 \mathrm{dm}^{3}$ capacity, filled with a substrate, produced by the Hartmann company, based on highmoor peat and humic peat. The ready-to-use substrate included PGMix NPK 14:16:18 compound fertilizer, supplemented with microelements, at the amount of $1.0 \mathrm{~kg} \cdot \mathrm{m}^{-3}$. A substrate $\mathrm{pH}$ level ranged from 5.5 to 6.5 . In each pot three seeds were planted at a depth of $1 \mathrm{~cm}$. Afterwards the pots were placed in a growth chamber fitted with daylight fluorescent tubes (Philips TLD $36 \mathrm{~W}$ ) and air flow, with an illumination of $16 \mathrm{~h}$ a day. The average temperature was $23{ }^{\circ} \mathrm{C}$ and the relative humidity $60 \%$.

Plants in the growth chamber were exposed to electromagnetic fields emitted by a specially designed device (EM emitter), as shown in Figure 1, for 20 days. The device emitting electromagnetic fields is composed of 3 spiral coils, constructed using a glass-epoxy laminate coated with copper $(20 \mu \mathrm{m})$, which is used for printed circuits. The coils are placed directly behind the upper wall of the housing which is made of plastic and connected by electrical wires. The wiring diagram is shown in Figure 1. The electrical wires are separated from the coils at a distance of about $5 \mathrm{~cm}$. The distance between the coils is $15 \mathrm{~cm}$. The electricity receiver is a $57 \mathrm{~W}$ halogen bulb, which was placed in the lamp outside the casing of the device, within a few meters distance to minimize the influence of thermal radiation of the bulb on the tested object. A black shade on the lamp protected against light exiting to the outside and its possible influence on the experiment's objects.

Three sectors were separated on the device. Thus different types of electromagnetic fields were produced. They were marked as "E" - a sector emitting electromagnetic radiation with the predominance of the electrical component, "EM" - a sector emitting 
electromagnetic radiation without domination of its components and "M" - a sector with a predominance of magnetic component. The method for creating the predominance of electric (E) and magnetic field (M) is shown in the diagram (Fig. 1). When the bulb is lit, between the bulb and zero (neutral) there is a predominance of magnetic field $(\mathrm{M})$, between the lit bulb and the phase (live) there is electric and magnetic, where the antenna is connected only to the phase (live) then there is a predominance of electric field (E). "EM" a sector emitting electromagnetic radiation, where the electric component "E" and the magnetic component "M" are at their maximum values. Such a phenomenon occurs when one of the three sectors of the radiating antenna is placed between the receiver (in this case a $57 \mathrm{~W}$ bulb), which is installed from the zero potential side, and on the other side, the sector is connected from the phase (live) side ( $230 \mathrm{~V}$ in this case).

\section{$\mathrm{E}$}

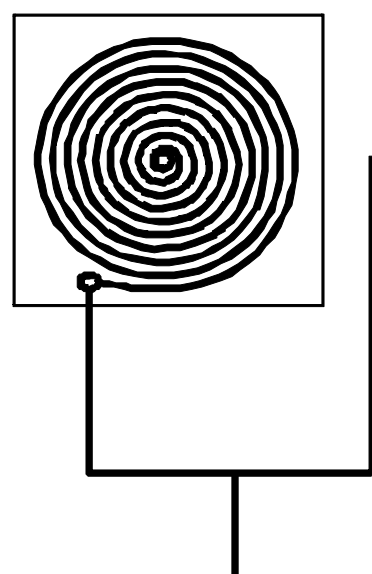

EM
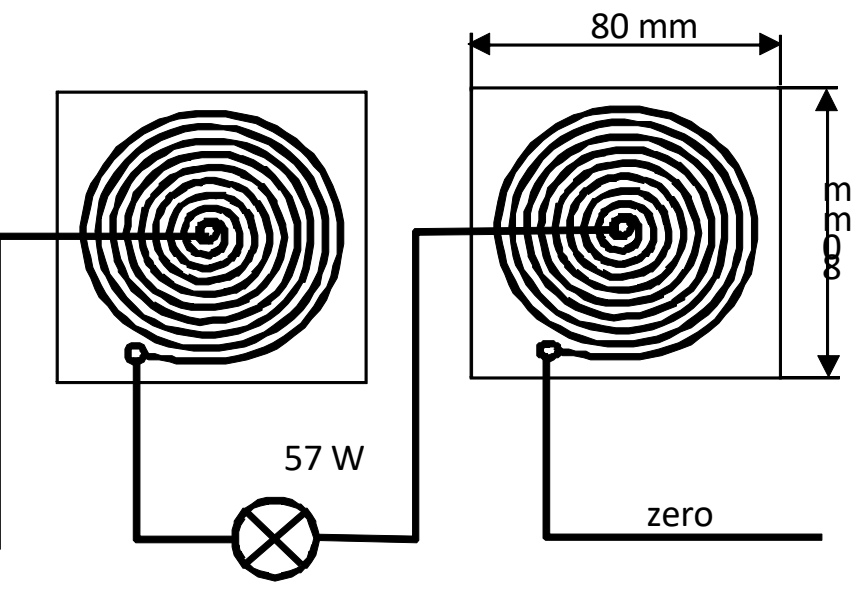

phase $\sim 230 \mathrm{~V}$

Fig. 1. Schematic diagram of the equipment used in the application of EMF

Table 1

Values of the intensity of electromagnetic fields measured $13 \mathrm{~mm}$ above the field generating device

\begin{tabular}{|c|c|c|c|}
\hline Components & Sector E & Sector EM & Sector M \\
\hline SE & $2290 \mathrm{~V} \cdot \mathrm{m}^{-1}$ & $2330 \mathrm{~V} \cdot \mathrm{m}^{-1}$ & $136 \mathrm{~V} \cdot \mathrm{m}^{-1}$ \\
\hline SM & $0.073 \mu \mathrm{T}$ & $4.880 \mu \mathrm{T}$ & $4.710 \mu \mathrm{T}$ \\
\hline
\end{tabular}

SE - electrical component, SM - magnetic component, Sector E - a sector emitting electromagnetic field with the predominance of the electrical component, Sector EM - a sector emitting electromagnetic field without domination of its components, Sector M - a sector emitting electromagnetic field with a predominance of the magnetic component

Pots with seeds were placed individually directly on the top of the device in the mentioned sectors, emitting differential electromagnetic fields. Each treatment included four replications i.e. four pots. Specific values of field components generated by the device 
are shown in Table 1. The different values of the electric field intensity and magnetic induction that are emitted by individual sectors given in the table were obtained thanks to the appropriate connection of the antenna with the receiver, in the form of a $57 \mathrm{~W}$ light bulb. Measurements of electromagnetic fields were made $13 \mathrm{~mm}$ above the field generating device using a Maschek E-100.

For comparison, the growth of runner bean plants in sectors E, EM and M of the field generating device, after its precise covering with the shielding material ADR TEX was evaluated. ADR TEX has been developed and patented by Wosinski [18, 19]. He has designed an advanced technology based on a nanocomposite in which the electric component of the electromagnetic radiation is absorbed by water dispersed within a dielectric matrix in various ways. As the frequencies of the dielectric absorption bands of water are determined by its state of aggregation (Fig. 2), an ice-like behaviour of water has been engineered by nanopore confinement. This advanced dielectric composite consists of a polymer matrix in which water is randomly dispersed in various ways. The composite exhibits high dielectric absorption in the low-frequency range and does not need grounding. The shielding ability of the composite can be tailored to various applications by selecting an appropriate microstructure for the dielectric matrix (varying the pore sizes by processing conditions or choosing characteristic properties) and by loading it with aqueous solutions of various hydrated salts and modifiers. The composites exhibits a high dielectric absorption and shield electric fields within the frequency range from $\sim 100 \mathrm{mHz}$ to $\sim 100 \mathrm{kHz}$. The electric field strength can be decreased by about two orders of magnitude, and the harmful effects of the electric component of electromagnetic fields on living organisms can be lowered considerably.

Figure 2 shows the frequency dependence of dielectric absorption of the matrix impregnated with the aqueous solution containing $\mathrm{MgCl}_{2}$ and other modifiers.

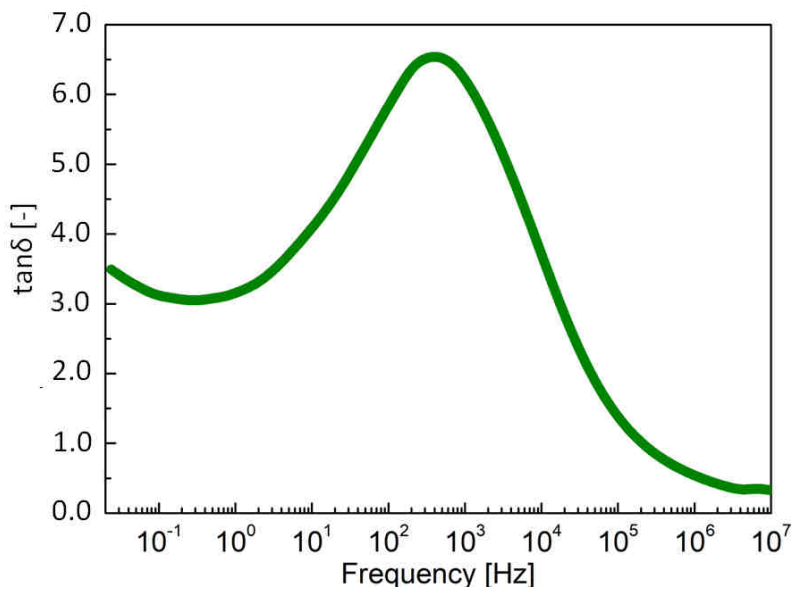

Fig. 2. Room temperature frequency dependence of $\tan \delta$ for a sample of ADR TEX LF fabric shield made with $\mathrm{ADR}^{\circledR}$ Technology (relative humidity $46 \%$ )

An example of the shielding efficiency of such a flexible EMF screen, composed of an active part consisting of a composite with a dielectric matrix made from a selected fabric inserted between two protective layers, is shown in Figure 2. Comparing the field 
distributions shown in Figure $3 \mathrm{a}$ and $\mathrm{b}$ one can observe that the electric field shielding is highly efficient.
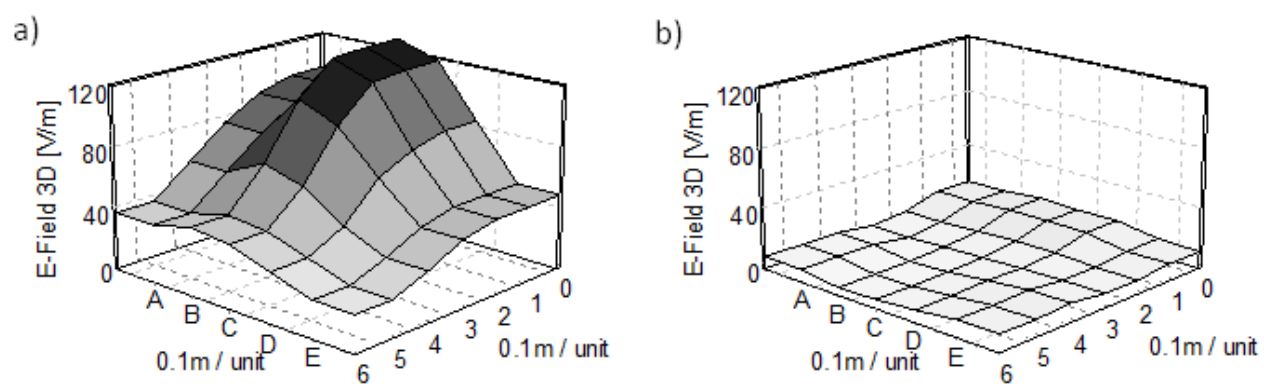

Fig. 3. a) Spatial distribution of electric field over an electrical source without shielding; b) electric field distribution over the same electrical source after shielding with a flexible dielectric screening

Specific values of field components generated by the device after shielding with ADR TEX screen, in particular sectors are shown in Table 2.

Values of the intensity of electromagnetic fields after shielding with ADR TEX

\begin{tabular}{|c|c|c|c|}
\hline Components & Sector E & Sector EM & Sector M \\
\hline SE & $215 \mathrm{~V} \cdot \mathrm{m}^{-1}$ & $207 \mathrm{~V} \cdot \mathrm{m}^{-1}$ & $185 \mathrm{~V} \cdot \mathrm{m}^{-1}$ \\
\hline $\mathrm{SM}$ & $0.141 \mu \mathrm{T}$ & $5.110 \mu \mathrm{T}$ & $5.140 \mu \mathrm{T}$ \\
\hline
\end{tabular}

For explanations see Table 1

For 9 days after seed sowing $\left(29^{\text {th }}\right.$ of September to $7^{\text {th }}$ of October) the numbers of seedlings in a given stage of vegetative development were determined. Five stages of the seedling development were identified, based on the modified BBCH scale, a universal scale using a decimal code for the description of the growth stages of crops [20]:

9 - emergence: shoot breaks through soil surface;

9.5 - shoot forms a hook, first leaves visible;

10 - the hook straightens out, leaves folded;

11 - single leaves unfolded, elongation of a first internode;

12 - first compound leaves unfolded, elongation of a second internode.

When the plants reached the developmental stage of the first compound leaves, only the strongest plant was left in each pot for further observations, other plants were removed. The length of first and second internodes, the length and width of single leaves and leaflets of compound leaves were measured four times at 3-4 day intervals $\left(7^{\text {th }}, 11^{\text {th }}, 14^{\text {th }}\right.$, and $18^{\text {th }}$ of October). Measurements were made with a ruler, within an accuracy of $1 \mathrm{~mm}$. Additionally, the index of leaf greenness (SPAD) was determined twice at 4-day intervals $\left(14^{\text {th }}\right.$ and $18^{\text {th }}$ of October) by means of a Yara N-Tester apparatus. This measurement is used to evaluate the intensity of the green colour of the leaves and is calculated as a quotient of light absorption connected with the presence of chlorophyll at the wavelength of $650 \mathrm{~nm}$ and the absorption by the leaf tissue at a wavelength of $940 \mathrm{~nm}$ [21].

The results obtained were evaluated by a one-way analysis of variance followed by Duncan's multiple range test, at a level $\alpha=0.05$. 


\section{Results}

Electromagnetic fields with the predominance of the electrical component and without domination of its components delayed initial emergence of runner bean seedlings. Shielding of electromagnetic field without domination of its components with ADR TEX screen protected against its negative impact on the emergence rate of young runner bean seedlings (Fig. 4).

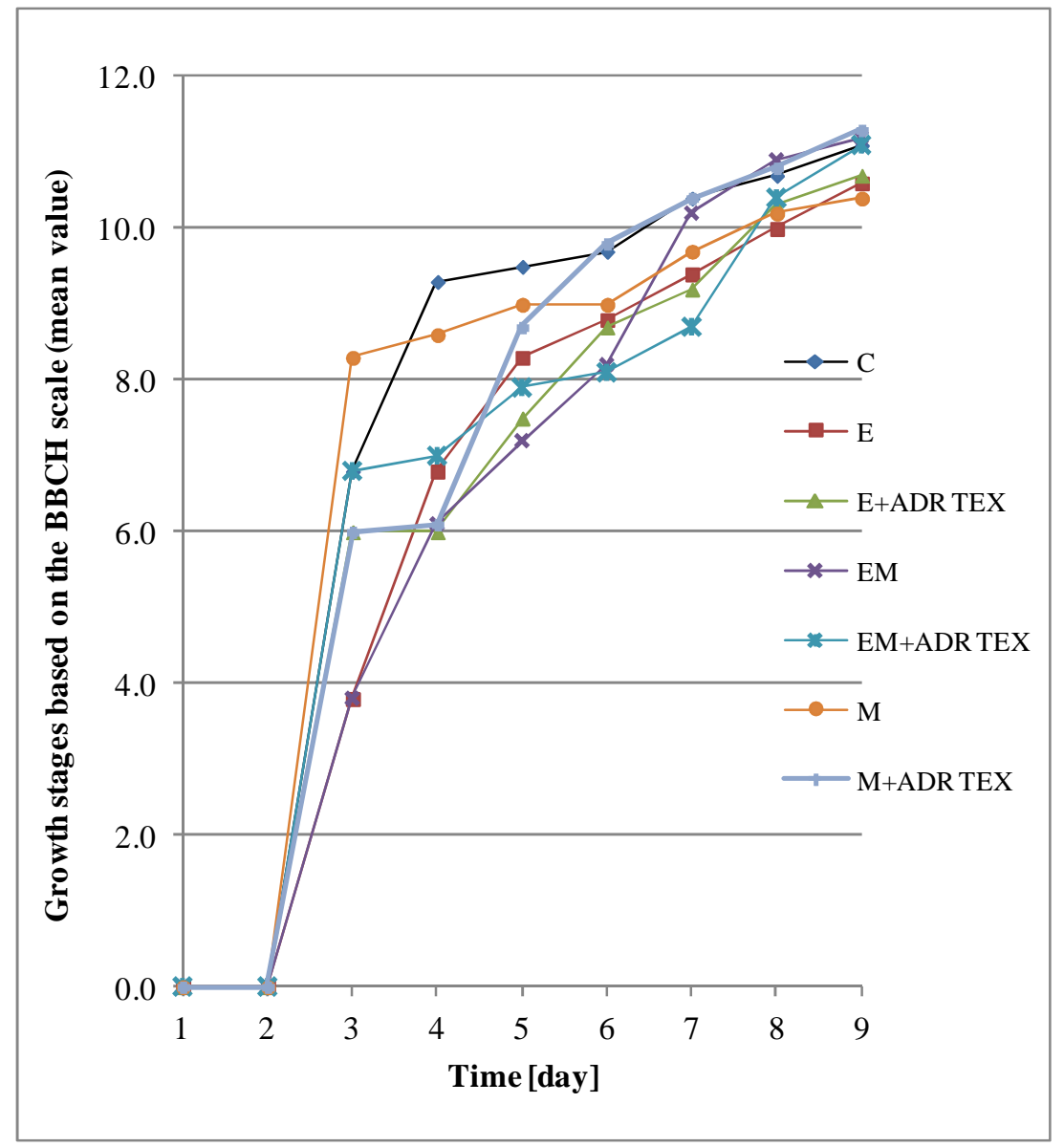

Fig. 4. Effects of electromagnetic fields and their shielding on the rate of seedling development in runner beans; C - untreated seeds (control), E - electromagnetic radiation with the predominance of the electrical component, E+ADR TEX - electromagnetic field with the predominance of the electrical component shielded by an ADR TEX screen, EM - electromagnetic field without domination of its components, EM+ADR TEX - electromagnetic field without domination of its components shielded by an ADR TEX screen, $M$ - electromagnetic field with a predominance of magnetic the component

In the third day from seed sowing the percentages of seedlings at stage 9 (shoot emerged through soil surface) were lower by $33.3 \%$ after exposure to electromagnetic field 
with the predominance of the electrical component and electromagnetic field without domination of its components (E and EM) compared to the control $(75 \%)$. Electromagnetic field with the predominance of magnetic component $(\mathrm{M})$ did not influence negatively the speed of seedling emergence. Shielding of electromagnetic fields by means of ADR TEX screen (E + ADR TEX and EM + ADR TEX) effectively protected emerging seedlings and the numbers of seedlings in the development stage 9 were similar to the control.

Table 3

Effects of electromagnetic fields and their shielding on the length of internodes in runner bean plants

\begin{tabular}{|c|c|c|c|c|c|}
\hline \multirow[b]{2}{*}{ Date } & \multirow[b]{2}{*}{ Treatment } & \multicolumn{2}{|c|}{ Length of internode [cm] } & \multicolumn{2}{|c|}{ Internode I + II } \\
\hline & & $\mathbf{I}$ & II & $\begin{array}{c}\text { Length } \\
{[\mathrm{cm}]}\end{array}$ & $\begin{array}{c}\text { Difference compared to } \\
\text { control [\%] }\end{array}$ \\
\hline \multirow{7}{*}{07.10 .2016} & Control & $9.0 \mathrm{~b}$ & -- & -- & -- \\
\hline & $\mathrm{E}$ & $4.3 \mathrm{a}$ & -- & -- & -- \\
\hline & E +ADR TEX & $6.8 \mathrm{ab}$ & -- & -- & -- \\
\hline & EM & $5.3 \mathrm{a}$ & -- & -- & -- \\
\hline & EM + ADR TEX & $7.6 \mathrm{ab}$ & -- & -- & -- \\
\hline & $\mathrm{M}$ & $6.5 \mathrm{ab}$ & -- & -- & -- \\
\hline & $\mathrm{M}+\mathrm{ADR}$ TEX & $7.4 \mathrm{ab}$ & -- & -- & -- \\
\hline \multirow{7}{*}{ 11.10.2016 } & Control & $9.6 \mathrm{~b}$ & $7.6 \mathrm{ab}$ & $17.8 \mathrm{~b}$ & -- \\
\hline & $\mathrm{E}$ & $6.0 \mathrm{a}$ & $7.3 \mathrm{ab}$ & $12.1 \mathrm{ab}$ & $\downarrow 32.1$ \\
\hline & E + ADR TEX & $7.6 \mathrm{ab}$ & $8.9 \mathrm{~b}$ & $16.1 \mathrm{ab}$ & $\downarrow 9.8$ \\
\hline & EM & $5.0 \mathrm{a}$ & $4.5 \mathrm{a}$ & $10.2 \mathrm{a}$ & $\downarrow 42.8$ \\
\hline & EM + ADR TEX & $8.3 \mathrm{ab}$ & $9.1 \mathrm{~b}$ & $16.7 \mathrm{ab}$ & $\downarrow 6.3$ \\
\hline & $\mathrm{M}$ & $7.1 \mathrm{ab}$ & $8.8 \mathrm{~b}$ & $14.1 \mathrm{ab}$ & $\downarrow 20.9$ \\
\hline & $M+$ ADR TEX & $8.0 \mathrm{ab}$ & $8.2 \mathrm{ab}$ & $16.6 \mathrm{ab}$ & $\downarrow 6.9$ \\
\hline \multirow{7}{*}{14.10 .2016} & Control & $9.9 \mathrm{~b}$ & $8.2 \mathrm{ab}$ & $16.9 \mathrm{~b}$ & -- \\
\hline & $\mathrm{E}$ & $5.0 \mathrm{a}$ & $7.6 \mathrm{ab}$ & $12.6 \mathrm{ab}$ & $\downarrow 25.4$ \\
\hline & E + ADR TEX & $7.6 \mathrm{ab}$ & $8.8 \mathrm{~b}$ & $16.5 \mathrm{~b}$ & $\downarrow 2.4$ \\
\hline & EM & $6.0 \mathrm{a}$ & $4.5 \mathrm{a}$ & $10.5 \mathrm{a}$ & $\downarrow 37.8$ \\
\hline & EM + ADR TEX & $8.3 \mathrm{ab}$ & $8.9 \mathrm{~b}$ & $17.1 \mathrm{~b}$ & $\uparrow 1.8$ \\
\hline & $\mathrm{M}$ & $7.1 \mathrm{ab}$ & $7.3 \mathrm{ab}$ & $14.4 \mathrm{ab}$ & $\downarrow 14.5$ \\
\hline & $M+$ ADR TEX & $8.0 \mathrm{ab}$ & $9.1 \mathrm{~b}$ & $17.1 \mathrm{~b}$ & $\uparrow 1.5$ \\
\hline \multirow{7}{*}{18.10 .2016} & Control & $9.9 \mathrm{~b}$ & $8.2 \mathrm{ab}$ & $18.1 \mathrm{~b}$ & -- \\
\hline & $\mathrm{E}$ & $5.0 \mathrm{a}$ & $7.6 \mathrm{ab}$ & $12.6 \mathrm{ab}$ & $\downarrow 30.5$ \\
\hline & E + ADR TEX & $7.6 \mathrm{ab}$ & $8.8 \mathrm{~b}$ & $16.5 \mathrm{ab}$ & $\downarrow 9.1$ \\
\hline & EM & $6.0 \mathrm{a}$ & $4.5 \mathrm{a}$ & $10.5 \mathrm{a}$ & $\downarrow 42.1$ \\
\hline & EM + ADR TEX & $8.3 \mathrm{ab}$ & $8.9 \mathrm{~b}$ & $17.2 \mathrm{~b}$ & $\downarrow 5.3$ \\
\hline & $\mathrm{M}$ & $7.1 \mathrm{ab}$ & $7.3 \mathrm{ab}$ & $14.4 \mathrm{ab}$ & $\downarrow 20.4$ \\
\hline & $\mathrm{M}+\mathrm{ADR}$ TEX & $8.0 \mathrm{~b}$ & $9.1 \mathrm{~b}$ & $17.1 \mathrm{~b}$ & $\downarrow 5.5$ \\
\hline
\end{tabular}

Means in columns followed by the same letters are not significantly different at $\alpha=0.05$ level according to Duncan's test. $\downarrow$ - decrease; $\uparrow$ - increase; For other explanations see Figure 4

In the fourth day after sowing, in control $50 \%$ of shoots formed a hook (stage 9.5). Seedlings at this stage of development were not observed when electromagnetic field with the predominance of the electrical component was applied with and without shielding

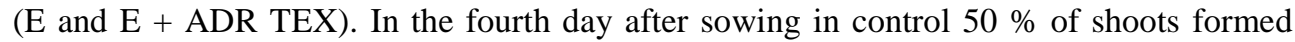
a hook (stage 9.5). After exposure to electromagnetic field without domination of its components $25 \%$ of seedlings was at stage 9.5 and the application of ADR TEX screen $(\mathrm{EM}+\mathrm{ADR} \mathrm{TEX})$ increased the percentage of the seedlings at this stage of development to $41.7 \%$. The highest percentage of shoots forming a hook was found after exposure to 
electromagnetic field with the predominance of magnetic component $(66.7 \%)$. However, shielding with ADR TEX screen (M + ADR TEX) reduced the percentage of these seedlings to $25 \%$.

After exposure to electromagnetic field with the predominance of the electrical component (E) only $16.7 \%$ of shoots formed a hook in the fifth day after sowing and in case of shielding with ADR TEX screen (E + ADR TEX) none of the seedlings was at this stage of development. At the same time in the control $41.7 \%$ of seedlings had the straightened out hook (stage 10). In EM and EM + ADR TEX treatments the percentages of seedlings in stage 10 of development were respectively 33.3 and $41.7 \%$. The highest percentage of seedlings with the straightened out hook was observed after exposure to electromagnetic field with the predominance of magnetic component $(66.7 \%)$. Shielding with ADR TEX screen (M + ADR TEX) reduced the percentage of these seedlings to $25 \%$.

After 8-9 days from sowing the differences among the treatments in the rate of seedling development were negligible (Fig. 4).

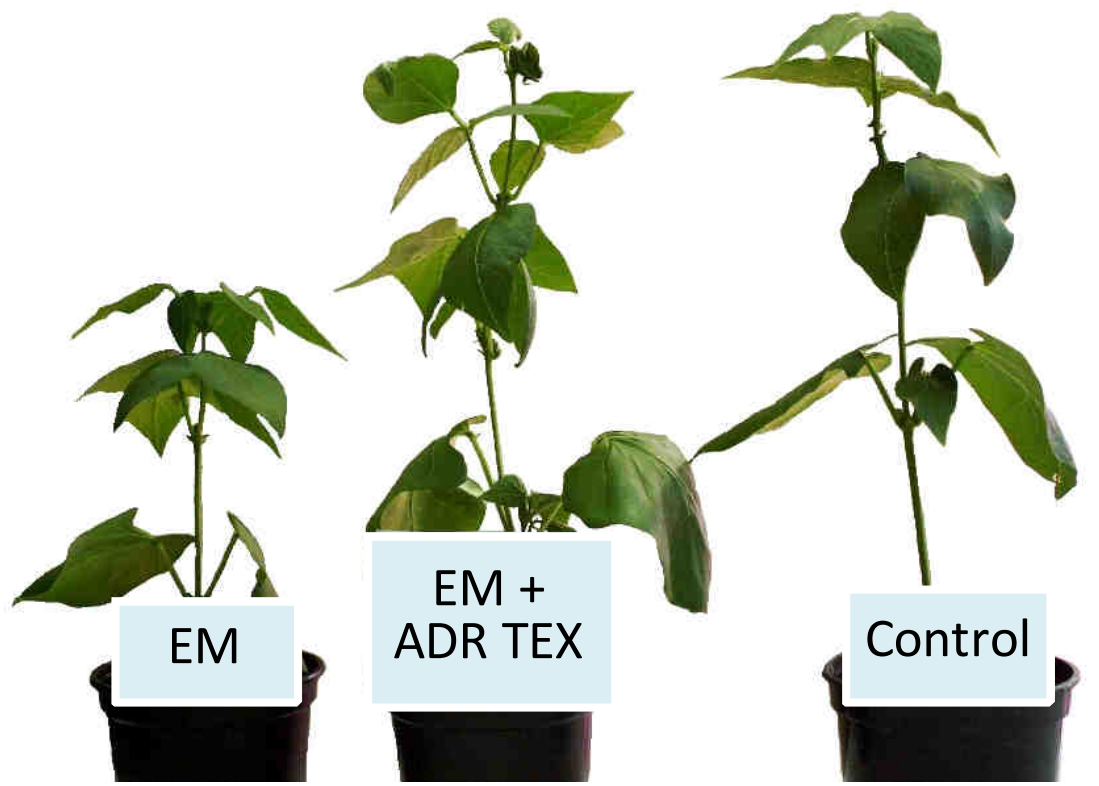

Fig. 5. The growth of runner bean plants exposed to the electromagnetic field without domination of its components, without shielding (EM) and after shielding with ADR TEX screen $(\mathrm{EM}+\mathrm{ADR} \mathrm{TEX})$ and in control

Exposure of plants to electromagnetic fields affected their height. Plants exposed to electromagnetic radiation without domination of its components (EM) had the lowest height and the shortest internodes. The average total length of first and second internodes, on particular days of the measurements, was significantly lower compared to control (by 37.83-42.78\%). The considerable decrease in a plant height was observed also after exposure to electromagnetic field with the predominance of the electrical component (E). The average total length of first and second internodes was lower than in the control by 25.37-32.12\%. Electromagnetic field with the predominance of magnetic component (M) 
had also a negative influence on plant growth. The average total length of first and second internodes was lower by $14.54-20.90 \%$ compared to the control, but the differences were not statistically significant (Table 3 ).

Shielding of electromagnetic field with ADR TEX screen (E + ADR TEX, EM + ADR TEX, M + ADR TEX) efficiently protected against its negative impact on the plant growth. The lengths of internodes in these treatments did not differ significantly from those in the control (Table 3, Fig. 5).

Exposure of plants to electromagnetic fields without their shielding as well as with shielding by means of ADR TEX screen did not affect the size of leaves. In general the average length and width of single leaves and leaflets in compound leaves did not differ significantly from the values of these parameters in the control (Table 4).

Table 4

Effects of electromagnetic fields and their shielding on the size of leaves and SPAD index in runner beans

\begin{tabular}{|c|c|c|c|c|c|c|}
\hline \multirow[t]{2}{*}{ Date } & \multirow[t]{2}{*}{ Treatment } & \multicolumn{2}{|c|}{$\begin{array}{l}\text { Single leaf } \\
{[\mathrm{cm}]}\end{array}$} & \multicolumn{2}{|c|}{$\begin{array}{c}\text { Leaflet of compound } \\
\text { leaf }[\mathrm{cm}]\end{array}$} & \multirow[t]{2}{*}{ SPAD index } \\
\hline & & Width & Length & Width & Length & \\
\hline \multirow{7}{*}{07.10 .2016} & Control & $7.4 \mathrm{~b}$ & $9.5 \mathrm{~b}$ & 0 & 0 & 0 \\
\hline & $\mathrm{E}$ & $7.3 \mathrm{~b}$ & $9.5 \mathrm{~b}$ & 0 & 0 & 0 \\
\hline & E + ADR TEX & $5.6 \mathrm{a}$ & $7.0 \mathrm{a}$ & 0 & 0 & 0 \\
\hline & EM & $8.3 \mathrm{~b}$ & $9.3 \mathrm{~b}$ & 0 & 0 & 0 \\
\hline & EM + ADR TEX & $4.5 \mathrm{a}$ & $9.8 \mathrm{~b}$ & 0 & 0 & 0 \\
\hline & $\mathrm{M}$ & $8.0 \mathrm{~b}$ & $9.9 \mathrm{~b}$ & 0 & 0 & 0 \\
\hline & M + ADR TEX & $7.5 \mathrm{~b}$ & $9.4 \mathrm{~b}$ & 0 & 0 & 0 \\
\hline \multirow{7}{*}{ 11.10.2016 } & Control & $9.2 \mathrm{a}$ & $11.4 \mathrm{ab}$ & $2.8 \mathrm{a}$ & $5.0 \mathrm{a}$ & 0 \\
\hline & $\mathrm{E}$ & $9.6 \mathrm{a}$ & $12.3 \mathrm{ab}$ & $3.6 \mathrm{a}$ & $6.5 \mathrm{a}$ & 0 \\
\hline & E + ADR TEX & $9.3 \mathrm{a}$ & $10.7 \mathrm{a}$ & $3.9 \mathrm{a}$ & $6.6 \mathrm{a}$ & 0 \\
\hline & EM & $10.3 \mathrm{a}$ & $11.1 \mathrm{ab}$ & $3.3 \mathrm{a}$ & $6.3 \mathrm{a}$ & 0 \\
\hline & EM + ADR TEX & $10.6 \mathrm{a}$ & $12.7 \mathrm{~b}$ & $3.9 \mathrm{a}$ & $7.4 \mathrm{a}$ & 0 \\
\hline & $\mathrm{M}$ & $10.4 \mathrm{a}$ & $12.3 \mathrm{ab}$ & $3.4 \mathrm{a}$ & $6.0 \mathrm{a}$ & 0 \\
\hline & M + ADR TEX & $4.5 \mathrm{a}$ & $12.3 \mathrm{ab}$ & $4.1 \mathrm{a}$ & $6.3 \mathrm{a}$ & 0 \\
\hline \multirow{7}{*}{14.10 .2016} & Control & $9.5 \mathrm{a}$ & $11.7 \mathrm{ab}$ & $4.2 \mathrm{a}$ & $7.4 \mathrm{a}$ & $47.2000 \mathrm{bc}$ \\
\hline & $\mathrm{E}$ & $9.9 \mathrm{a}$ & $12.6 \mathrm{~b}$ & $4.5 \mathrm{a}$ & $7.9 \mathrm{a}$ & $48.5750 \mathrm{c}$ \\
\hline & E + ADR TEX & $9.4 \mathrm{a}$ & $11.0 \mathrm{a}$ & $4.9 \mathrm{a}$ & $8.0 \mathrm{a}$ & $41.7250 \mathrm{a}$ \\
\hline & EM & $10.6 \mathrm{a}$ & $11.6 \mathrm{ab}$ & $4.0 \mathrm{a}$ & $7.2 \mathrm{a}$ & $44.4000 \mathrm{a}-\mathrm{c}$ \\
\hline & EM + ADR TEX & $10.7 \mathrm{a}$ & $12.9 \mathrm{~b}$ & $4.6 \mathrm{a}$ & $8.6 \mathrm{a}$ & $43.9625 \mathrm{ab}$ \\
\hline & $\mathrm{M}$ & $10.5 \mathrm{a}$ & $12.6 \mathrm{~b}$ & $4.2 \mathrm{a}$ & $7.6 \mathrm{a}$ & $47.2625 \mathrm{bc}$ \\
\hline & $\mathrm{M}+\mathrm{ADR}$ TEX & $10.8 \mathrm{a}$ & $12.8 \mathrm{~b}$ & $4.8 \mathrm{a}$ & $8.0 \mathrm{a}$ & $45.6125 \mathrm{a}-\mathrm{c}$ \\
\hline \multirow{7}{*}{18.10 .2016} & Control & $9.6 \mathrm{a}$ & $12.0 \mathrm{ab}$ & $4.6 \mathrm{a}$ & $7.9 \mathrm{a}$ & $44.5750 \mathrm{ab}$ \\
\hline & $\mathrm{E}$ & $10.1 \mathrm{a}$ & $12.8 \mathrm{~b}$ & $4.9 \mathrm{a}$ & $8.4 \mathrm{a}$ & $46.5375 \mathrm{~b}$ \\
\hline & E + ADR TEX & $9.5 \mathrm{a}$ & $11.0 \mathrm{a}$ & $5.6 \mathrm{a}$ & $9.3 \mathrm{a}$ & $41.8625 \mathrm{ab}$ \\
\hline & EM & $10.7 \mathrm{a}$ & $11.6 \mathrm{ab}$ & $4.3 \mathrm{a}$ & $7.9 \mathrm{a}$ & $41.4250 \mathrm{a}$ \\
\hline & EM + ADR TEX & $10.8 \mathrm{a}$ & $12.9 \mathrm{~b}$ & $5.0 \mathrm{a}$ & $9.1 \mathrm{a}$ & $42.5000 \mathrm{ab}$ \\
\hline & $\mathrm{M}$ & $10.5 \mathrm{a}$ & $12.7 \mathrm{~b}$ & $5.0 \mathrm{a}$ & $8.6 \mathrm{a}$ & $45.4500 \mathrm{ab}$ \\
\hline & $M+$ ADR TEX & $10.9 \mathrm{a}$ & $13.0 \mathrm{~b}$ & $5.7 \mathrm{a}$ & $8.6 \mathrm{a}$ & $46.0750 \mathrm{ab}$ \\
\hline
\end{tabular}

Means in columns followed by the same letters are not significantly different at $\alpha=0.05$ level according to Duncan's test. For other explanations see Figure 4

Electromagnetic fields and their shielding did not influence the index of leaf greenness (SPAD) compared to the control. Only in the case of the treatment when plants were subjected to electromagnetic field with the predominance of the electrical component 
combined with its shielding (E + ADR TEX) a significant reduction in the value of SPAD index was noted during the first measurement (Table 4).

\section{Discussion}

It has been found in the present investigation that electromagnetic fields with the predominance of the electrical component and without domination of its components ( $E$ and $E M$ ) delayed initial emergence of runner bean seedlings. On the contrary, electromagnetic field with the predominance of magnetic component (M) showed a small positive impact on the initial seedling emergence rate. However, after 8-9 days from sowing the differences among the treatments and control in the rate of seedling development were negligible. The electric strength in sectors E and EM of the device emitting electromagnetic fields was 2290 and $2330 \mathrm{~V} \cdot \mathrm{m}^{-1}$ respectively, whereas values of magnetic field induction were only 0.073 and $4.880 \mu \mathrm{T}$. In the case of sector M the value of electric intensity was over sixteen times lower than in sectors E and EM and magnetic field induction was $4.710 \mu \mathrm{T}$. Das and Bhattacharya [22] found that the application of electric field of $1.5 \mathrm{kV} \cdot \mathrm{m}^{-1}$ to gram (Cicer arietinum L.) seeds for 20 min decreased the root length in 4 day old seedlings by $14 \%$. With the increase of electric field strength the root growth was reduced further. Rajendra et al. [23] reported that the exposure of germinating broad bean seedlings to fields at 5,50 and $100 \mu \mathrm{T}$ did not affect their physical parameters and major biochemical constituents (sugar, protein and fat), but had an influence on the activity of enzymes involved in seed germination. $\alpha$-amylase activity decreased at 5, 50 and $100 \mu \mathrm{T}$ on day 2 and 4 of growth. B-amylase and protease showed a significant reduction in activity on day 2 and 4 of growth at $100 \mu \mathrm{T}$, whereas the activity of lipase significantly decreased only on day 2 of growth at $100 \mu \mathrm{T}$. However, at day 8 of growth, all enzymes were returned to control values. Rochalska and Orzeszko-Rywka [24] did not observe an effect of alternating magnetic field with low frequency 16 and $50 \mathrm{~Hz}$ (flux density $5 \mathrm{mT}$ ) on seed germination and the seedling length of spring wheat at $20^{\circ} \mathrm{C}$. However, under stressed conditions, at the low temperature of $5{ }^{\circ} \mathrm{C}$ a positive influence of the treatment was observed. According to the authors magnetic fields can be responsible for fast mobilization of reserve materials during seed germination under unfavourable conditions. Fischer et al. [25] found that 12 day old sunflower seedlings under continuous exposure to $162 / 3 \mathrm{~Hz}$ magnetic fields with the induction of $20 \mu \mathrm{T}$ showed small, but significant increases in total fresh weight, shoot and root fresh weights, whereas dry weight and germination rate remained unaffected. Treated wheat seedlings exhibited marginally higher root fresh and dry weights, total fresh weight and higher germination rate. Radhakrishnan and Kumari [26] subjected soybean seeds to pulsed magnetic field with low intensity $(1500 \mathrm{nT})$ and frequency $(10 \mathrm{~Hz})$ for 20 days, $5 \mathrm{~h}$ per day. The treatment increased the height, and the fresh and dry weight of 8 day old seedlings and the enhancement of protein content with the changes of protein profile were observed. In addition, the activity of some enzymes i.a. ß-amylase, acid phosphatase, polyphenol oxidase and catalase were enhanced while $\alpha$-amylase, alkaline phosphatase, protease and nitrate reductase activities declined. The authors also observed the increase in $\mathrm{Fe}, \mathrm{Cu}, \mathrm{Mn}, \mathrm{Zn}, \mathrm{K}$ and $\mathrm{Na}$ contents with a reduced level of $\mathrm{Ca}$. Treating faba bean seeds with $30 \mathrm{mT}$ magnetic field for $15 \mathrm{~s}$ increased amylolytic enzymes activity in seeds and seedlings and had a beneficial effect on seedling growth and development [27]. Yadav et al. [28] observed a higher activity of $\alpha$-amylase, $\beta$-amylase, catalase and peroxidase in rice seeds subjected to $25 \mathrm{mT}$ magnetic field for 15 to $90 \mathrm{~min}$ compared to untreated seeds. 
Cakmak et al. [29] reported that exposure of common bean and wheat seeds to static magnetic fields with the induction of $7 \mathrm{mT}$ improved their germination rate. However, the significant increase in shoot and root dry weights of 7 day old seedlings were found only in the case of wheat. De Souza et al. [30] observed accelerated and more uniform germination after treating tomato seeds with $60 \mathrm{~Hz}$ full-wave rectified sinusoidal non-uniform magnetic fields. The best results were found when field induction 160 and $200 \mathrm{mT}$ for $1 \mathrm{~min}$ was used. Seedlings, grown from seeds exposed to these magnetic fields, were characterized by significantly longer shoots and roots. The treated seeds showed a higher germination percentage after 4 to 7 days from sowing than untreated seeds, however after 14 days that phenomenon was not observed. Carbonell et al. [31] observed a stimulating effect of 125 and $250 \mathrm{mT}$ stationary magnetic fields on the first stages of growth of pea plants. The major increases occurred when seeds were treated continuously. Mroczek-Zdyrska et al. [32] reported that $130 \mathrm{mT}$ magnetic field stimulation promoted mitotic activity in meristematic cells in common bean roots. The authors did not observe an influence of the treatment on the fresh weight, length of roots and shoots, and the length and width of leaves in 14 day old seedlings. Stimulation with magnetic field did not affect either the chlorophyll and carotenoid contents in leaves. However, a marked increase in guaiacol peroxidase activity in leaves was noticed. Serdyukov and Novitskii [33] investigated the impact of weak magnetic field with the magnetic flux density of $185-650 \mu \mathrm{T}$ on activities of antioxidant enzymes in 5 day old radish seedlings. Magnetic fields in the range of 185-325 $\mu \mathrm{T}$ inhibited superoxide dismutase and catalase activity, whereas at higher values of magnetic induction enhanced activity of these enzymes.

In the present study, the continuous exposure of plants to differentiated electromagnetic fields adversely affected their growth. Plants exposed to electromagnetic radiation without domination of its components had the lowest height and the shortest internodes. The weakest effect was observed in case of the electromagnetic field with the predominance of magnetic component. Electromagnetic fields did not influence the size of leaves and the index of leaf greenness (SPAD). Soja et al. [34] examined the effects of an electromagnetic field from a high voltage $(380 \mathrm{kV})$ transmission line on the yield of winter wheat and corn cultivated underneath and near the transmission line. The average electric and magnetic field strengths at four distances from transmission line were between 0.2 and $4.0 \mathrm{kV} \cdot \mathrm{m}$ and between 0.4 and $4.5 \mu \mathrm{T}$, respectively. The researchers found that the wheat grain yields were higher by $7 \%$ in the plots with the lowest field exposure. The responses of the plants were more pronounced in years with drought periods during grain filling than in humid years. No significant differences were found for corn yields. Radhakrishnan and Kumari [26] found that soybean plants grown from seeds exposed to $1500 \mathrm{nT}$ pulsed magnetic field produced the higher numbers of leaves, pods and seeds than control plants. The length of pods and weight of seeds were either considerably higher than in the control. The exposure of wheat seeds to the low-frequency electromagnetic field $(16 \mathrm{~Hz}, 6 \mathrm{mT})$ for $9 \mathrm{~min}$ resulted in an increase in the height and weight of plants derived [35]. Root and stem lengths and dry weights of thyme seedlings were enhanced after $50 \mathrm{mT}$ electromagnetic field treatment for $15 \mathrm{~min}$ [36]. Jedlicka et al. [37] reported that $50 \mathrm{~Hz}$ electromagnetic fields with the induction of 20,40 and $60 \mathrm{mT}$ and the exposure time of 20 minutes a day had a stimulatory effect on plant growth and size of tomato fruits. According to Dannehl [9] and Schmiedchen et al. [38] the stimulatory or inhibitory effects of electric and magnetic fields are species specific and depend on the intensity, exposure time, application form and the physiological state of the plant development. 
It has been found that the shielding of electromagnetic radiation without domination of its components by means of ADR TEX screen protected against its negative impact on the emergence rate of young runner bean seedlings, but the shielding of electromagnetic field with the predominance of the electrical component did not protect against its negative influence on the seedling emergence rate. Application of ADR TEX screen efficiently protected plants against the negative impact of electromagnetic fields on their growth. The lengths of internodes in these treatments did not differ significantly from those in the control. Shielding decreased the electric field strength in sectors E and EM of the device emitting electromagnetic fields by over ten times. Hence, the harmful effects of the electric component on the plant growth were lowered considerably. At the same time a small increase in the magnetic field induction was observed in all sectors of the device. Dorna et al. [39] reported that exposure of carrot seeds to $40 \mathrm{mT}$ magnetic field combined with shielding of an alternating electric field with ADR-4 (Advanced Dielectric Radiation Trap) improved their germination capacity compared to untreated seeds.

\section{Conclusion}

1. Electromagnetic fields with the predominance of the electrical component and without domination of its components (E and EM) delayed initial emergence of runner bean seedlings.

2. Shielding of electromagnetic radiation without domination of its components by means of ADR TEX screen protected against its negative impact on the emergence rate of young runner bean seedlings. Shielding of electromagnetic field with the predominance of the electrical component did not protect against its negative influence on the seedling emergence rate.

3. Exposure of plants to differentiated electromagnetic fields adversely affected their growth. Plants exposed to electromagnetic radiation without domination of its components had the lowest height and the shortest internodes. The weakest effect was observed in the case of electromagnetic field with the predominance of the magnetic component.

4. Shielding of electromagnetic fields with ADR TEX screen efficiently protected against their negative impact on the plant growth. The lengths of internodes in these treatments did not differ significantly from those in the control.

5. Electromagnetic fields and their shielding did not influence the size of leaves and the index of leaf greenness (SPAD).

\section{References}

[1] Lewczuk B, Redlarski G, Żak A, Ziółkowska N, Przybylska-Gornowicz B, Krawczuk M. Influence of electric, magnetic, and electromagnetic fields on the circadian system: current stage of knowledge. Bio Med Res Int. 2014;169459. DOI: 10.1155/2014/169459.

[2] Gemici M, Demiray H, Gemici Y. Effects of electromagnetic fields produced by high voltage transmission on physiology of Juglans regia L. and Cerasus avium L. Moensch Ege Üniv Ziraat Fak Derg. 2013;50(2):129-35. Available from: https://dergipark.org.tr/download/article-file/59435.

[3] Biketi S, Kirui MSK, Mwonga S, Ngumbu R., Rono J. Effect of $50 \mathrm{~Hz}$ magnetic field on the chlorophyll content of Spinacia oleracea. $11^{\text {th }}$ JKUAT Scientific, Technol Industrialization Conf. 2016;52. Available from: http://journals.jkuat.ac.ke/index.php/jscp/article/view/1328/1094.

[4] Racuciu M, Creanga DE. Biological effects of low frequency electromagnetic field in Cucurbita pepo. Proc Third Moscow Int Symp Magnetism. 26-30 June 2005, Moscow, Russia. 2005;278-82. Available from: http://magn.ru/proc/pdf/278.pdf. 
[5] Michalak I, Lewandowska S, Niemczyk K, Detyna J, Bujak H, Arik P, et al. Germination of soybean seeds exposed to the static/alternating magnetic field and algal extract. Eng Life Sci. 2019;19:986-99. DOI: 10.1002/elsc.201900039.

[6] Nurbaity A, Nuraini A, Agustine E, Solihin MA, Setiawan A, Mbusango A. Enhanced seedling germination and growth of sorghum through pre-sowing seed magnetic field treatment. Int Seminar Congress Indonesian Soil Sci Soc. 2019. IOP Conf Series: Earth Environ Sci. 2019:393;012101. DOI: 10.1088/1755-1315/393/1/012101.

[7] Sudsiri ChJ, Jumpa N, Kongchana P, Ritchie RJ. Stimulation of oil palm (Elaeis guineensis) seed germination by exposure to electromagnetic fields. Sci Hortic. 2017:220:66-77. DOI: 10.1016/j.scienta.2017.03.036.

[8] Shrabangi A, Sheidai M, Majd A, Nabluni M, Dorranian D. Cytogenetic abnormalities caused by extremely low electromagnetic fields in canola. Sci Asia. 2010;36:292-6. DOI: 10.2306/scienceasia1513-1874.2010.36.292.

[9] Dannehl D. Effects of electricity on plant responses. Sci Hortic. 2018;234:382-92. DOI: 10.1016/j.scienta.2018.02.007.

[10] Moon JD, Chung HS. Acceleration of germination of tomato seed by applying AC electric and magnetic fields. J Electrostat. 2000;48:103-14. DOI: 10.1016/S0304-3886(99)00054-6.

[11] Molamofrad F, Lotfi M, Khazaei J, Tavakkol-Afshari R, Shaiegani-Akmal AA. The effect of electric field on seed germination and growth parameters of onion seeds (Allium cepa). Adv Crop Sci. 2013;3(4):291-8. Available from: https://www.researchgate.net/publication/236856128_The_effect_of_electric_field_on_seed_germination_ and_growth_parameters_of_onion_seeds_Allium_cepa.

[12] Janositz A, Knorr D. Microscopic visualization of pulsed electric field induced changes on plant cellular level. Innov Food Sci Emerg Technol. 2010;11(4):592-7. DOI: 10.1016/j.ifset.2010.07.004.

[13] Górski R, Kotwicka M, Skibińska I, Jendraszak M, Wosiński S. Effect of low-frequency electric field screening on motility of human sperm. Ann Agric Environ Med. 2020;27(3):427-34. DOI: 10.26444/aaem/116019.

[14] Górski R, Nowak-Terpiłowska A, Śledziński P, Baranowski M, Wosiński S. Morphological and cytophysiological changes in selected lines of normal and cancer human cells under the influence of a radio-frequency electromagnetic field. Ann Agric Environ Med. 2019. DOI: 10.26444/aaem/118260.

[15] Milham S. Historical evidence that electrification caused the 20th century epidemic of "diseases of civilization". Medical Hypotheses. 2010;74(2):337-45. DOI: 10.1016/j.mehy.2009.08.032.

[16] IARC (International Agency for Research on Cancer). Non-Ionizing Radiation, Part 1: Static and extremely low-frequency (ELF) electric and magnetic fields. IARC Monographs on the Evaluation of Carcinogenic Risks to Humans: 2002, volume 80. Lyon: IARC Press; 1-445. ISBN: 9789283215806. Available from: https://publications.iarc.fr/Book-And-Report-Series/Iarc-Monographs-On-The-Identification-OfCarcinogenic-Hazards-To-Humans/Non-ionizing-Radiation-Part-1-Static-And-Extremely-Low-frequencyELF-Electric-And-Magnetic-Fields-2002.

[17] C95.1-2019/Cor 1-2019 - IEEE approved draft standard for safety levels with respect to human exposure to electric, magnetic and electromagnetic fields, $0 \mathrm{~Hz}$ to $300 \mathrm{GHz}$ - Corrigendum 1. IEEE Standards Association; 2019. Available from: https://standards.ieee.org/standard/C95_1-2019.html.

[18] Wosiński S. Solution for impregnation of materials shielding low-frequency electric field and the shielding material. PAT.221223 Available from: https://patentscope. wipo.int/search/en/detail.jsf?docId=WO2010093270\&tab=PCTBIBLIO.

[19] Wosiński S. A composition for impregnating materials to shield against the effects of alternating electromagnetic fields, its application in coating/impregnating fibrous and/or porous matrices and materials containing the same. Patent application 20170349765; 2017. Available from: https://patents.justia.com/patent/20170349765.

[20] Lancashire PD, Bleiholder H, Langeluddecke P, Stauss R, van den Boom T, Weber E, et al. A uniform decimal code for growth stages of crops and weeds. Ann Appl Biol. 1991;119(3):561-601. DOI: 10.1111/j.1744-7348.1991.tb04895.x.

[21] Rodriguez IR, Miller GR. Using a chlorophyll meter to determine the chlorophyll concentration, nitrogen concentration, and visual quality of St. Augustine grass. HortSci. 2000;35:751-4. DOI: 10.21273/HORTSCI.35.4.751.

[22] Das R, Bhattacharya R. Impact of electromagnetic field on seed germination. Proc XXVIIIth URSI General Assembly, New Delhi, India, October 2005, ISBN: 8177649280, Paper KP.14(0983). Available from: www.ursi.org/proceedings/procGA05/pdf/KP.14(0983).pdf. 
[23] Rajendra P, Sujatha Nayak H, Sashidhar RB, Subramanyam C, Devendranath D, Gunasekaran B, et al. Effects of power frequency electromagnetic fields on growth of germianting Vicia faba L., the broad bean. Electromagn Biol Med. 2005;24:39-54. DOI: 10.1081/JBC-200055058.

[24] Rochalska M, Orzeszko-Rywka A. Magnetic field treatment improves seed performance. Seed Sci Technol. 2005;33:669-74. DOI: 10.15258/sst.2005.33.3.14.

[25] Fischer G, Tausz M, Köck M, Grill D. Effects of weak 16 2/3 magnetic fields on growth parameters of young sunflower and wheat seedlings. Bioelectromagnetics. 2004;25(8):638-41. DOI: 10.1002/bem.20058.

[26] Radhakrishnan R, Kumari BDR. Pulsed magnetic field: A contemporary approach offers to enhance plant growth and yield of soybean. Plant Physiol Biochem. 2012;51:139-44. DOI: 10.1016/j.plaphy.2011.10.017.

[27] Podleśna A, Bojarszczuk J, Podleśny J. Effect of pre-sowing magnetic field treatment on some biochemical and physiological processes in faba bean (Vicia faba L. spp. minor). J Pant Growth Regul. 2019;38:1153-60. DOI: 10.1007/s00344-019-09920-1.

[28] Yadav YM, Mahadik SG, Dalvi VV, Deogirikar AA, Burondkar MM, Vanave PB. Effect of magnetic treatment on enzyme activation of paddy (Oryza sativa L.). Int $J$ Curr Microbiol App Sci. 2018;7(10):3573-81. DOI: 10.20546/ijcmas.2018.710.414.

[29] Cakmak T, Dumlupinar R, Erdal S. Acceleration of germination and early growth of wheat and bean seedlings grown under various magnetic field and osmotic conditions. Bioelectromagnetics. 2009;31(2):120-9. DOI: 10.1002/bem.20537.

[30] De Souza A, Sueiro L, García D, Porras E. Extremely low frequency non-uniform magnetic fields improve tomato seed germination and early seedling growth. Seed Sci Technol. 2010;38:61-72. DOI: 10.15258/sst.2010.38.1.06.

[31] Carbonell MV, Flórez M, Martínez E, Maqueda R, Amaya JM. Study of stationary magnetic fields on initial growth of pea (Pisum sativum L.) seeds. Seed Sci Technol. 2011;39(3):673-9. DOI: 10.15258/sst.201139.3.15.

[32] Mroczek-Zdyrska M, Tryniecki Ł, Kornarzyński K, Pietruszewski S, Gagoś M. Influence of magnetic field stimulation on the growth and biochemical parameters in Phaseolus vulgaris L. J Microbiol Biotech Food Sci. 2016;5(6):548-51. DOI: 10.15414/jmbfs.2016.5.6.548-551.

[33] Serdyukov YA, Novitskii YI. Impact of weak permanent magnetic field on antioxidant enzyme activities in radish seedlings. Russ. J Plant Physiol. 2013;60(1):69-76. DOI: 10.1134/S1021443713010068.

[34] Soja G, Kunsch B, Gerzabek M, Reichenauer T, Soja AM, Rippar G, et al. Growth and yield of winter wheat (Triticum aestivum L.) and corn (Zea mays L.) near a high voltage transmission line. Bioelectromagnetics. 2003;24(2):91-102. DOI: 10.1002/bem;.10069.

[35] Levina NS, Tertyshnaya YV, Bidey IA, Elizarova OV, Shibryaeva LS. Presowing treatment of seeds of spring wheat with low-frequency electromagnetic field. Agricult Biol. 2017;52(3):580-7. DOI: 10.15389/agrobiology.2017.3.580eng.

[36] Nader A, Touraj MM, Nader J. Effects of electromagnetic field and ultrasonic waves on seed germination, seedling characteristics and essence percent of thymes (Thymus vulgaris L.). J Crop Ecophysiol (Agricult Sci). 2019;13(1):57-72. Available from: https://www.sid.ir/en/Journal/ViewPaper.aspx?ID=724037.

[37] Jedlička J, Paulen O, Ailer Š. Research of effect of low frequency magnetic field on germination, growth and fruiting of field tomatoes. Acta Horticulturae et Regiotecturae. 2015;1:1-4. DOI: 10.1515/ahr-2015-0001.

[38] Schmiedchen K, Petri AK, Driessen S, Bailey WH. Systematic review of biological effects of exposure to static electric fields. Part II: Invertebrates and plants. Environ Res. 2018;160:60-76. DOI: 10.1016/j.envres.2017.09.013.

[39] Dorna H, Górski R, Szopińska D, Tylkowska K, Jurga J, Wosiński S, et al. Effects of a permanent magnetic field together with the shielding of an alternating electric field on carrot seed vigour and germination. Ecol Chem Eng S. 2010;17(1):53-61. Available from: https://drive.google.com/file/d/1IfsFlFVf32vO1OlkNuu09220UjUAwWs/view. 